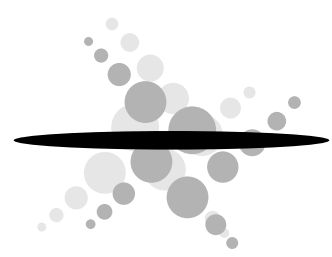

\title{
昆虫の飛行メカニズム (流体力学的視点から)
}

\author{
東京大学先端科学技術研究センター 河内啓二
}

\begin{abstract}
Flight mechanism of insect is different from that of our familiar system of aircraft, machinery, or bird. Recent studies quantitatively indicated that many features of insect flight mechanism, such as thin airfoil, high beating frequency, or continuous beating motion, well conform to the fluiddynamic condition given to the insect.
\end{abstract}

insect flight mechanism / thin airfoil section / beating motion / unsteady aerodynamics / Reynolds number / bio-fluiddynamics

\section{1.はじめに}

大空を自由に飛翔する鳥や昆虫は, 長い間人類を魅 了し続けてきた. しかし, 一見, 楽々と飛翔しているよ うに見えるこれらの生物たちも, 強大な重力に打ち勝 つために,さまざまな工夫を凝らし, また多大の犠牲を 払っている. 骨格は軽量化のために光の構造が規定さ れ, 食物は食べるや否や排泄に向かい, 脳や足もきわめ て単純かつ軽量である. 飛翔する生物の運動メカニズ ムが, ほとんど画一的に羽ばたき飛行であり, 翼の形状 も一見よく似ているのは, この厳しい環境に由来して いる. 海中や水中の生物が, 同じ流体中の運動でありな がら（つまり, 同じ基礎方程式 (ナビエーストークス の式)に支配されていながら), マグロやサバのように 尾ひれを振って前進するもの, ウナギやウツボのよう に胴体をくねらせて泳ぐもの, エビのように足も使う もの, さらにイカやクラゲのようにジェット推進をす るものまで, 極めて多樣性に富んでいる ${ }^{1)}$ のは, 好対 照である. 水中では, 浮力を使って重力に対抗でき, 運 動はただ推進力を発生すればよいという制約の櫯やか な環境か実現されているからである.

このように重力に対抗しなければならないという厳 しい環境が, 飛翔する生物の運動メカニズムや運動器 官の形状を, 飛ぶという目的のためだけに適応させて いる. 逆にいうと, これらのメカニズムや形状は, 飛ぶ という行動からとらえると非常に理解しやすいものと なっている.この点か生物の飛翔メカニズムを調べる 研究の, 大きな魅力となっている.

運動器官と光の目的が 1 対 1 に対応しているという
ことは, 現在の科学のレベルから見ると大変ありがた い. たとえば人間の手は, 野球のバットも握れば, 拳骨 という形で殴る道具ともなり, また指を折って数も数 える. このようにさまざまな目的に使われていると, 光 の形状や運動メカニズムがどう優れているかを調べる ことが大変難しい.

\section{2 . 昆虫の翅はなぜ薄いのか}

\section{1 翅の形状}

昆虫の翅は一般にきわめて薄い.一例として図 1 にト ンボの翅の平面形状と断面形状を示す. 構造の複雑な卜 ンボの翅では, 付け根から翼端に向かって網目状の黑色 の支脈が走り, 兴の間を透明な薄膜がおおつており, 支 脈はパイブ状の構造をしている. 翼弦長 (図1のA-A方 向の翼の長さ) は $10 \mathrm{~mm}$ 程度, 支脈の直径は太いもので $100 \mu \mathrm{m}$, 細いもので $10 \mu \mathrm{m}$, 薄膜の厚さは $2 \mu \mathrm{m}$ 程度なの で, 細かく見ると翼の表面に50倍程度の凸凹がつて いることになるが, これらは翼弦長に比べると無視でき るほど小さい. しかし断面形状に示すように, 全体に高 さ1〜2 $\mathrm{mm}$ 程度のギザギザがいていて, これは翼弦 長に比へて有意の大きさとなって翼断面 (翼型) を形成

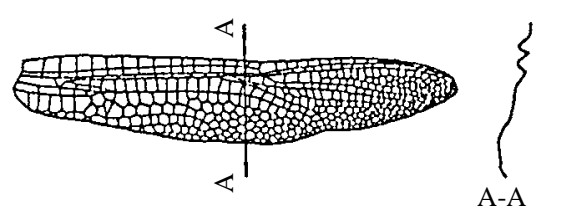

図1 トンボの翅

Flight Mechanism of Insect (From Standpoint of View of Bio-Fluiddynamics)

Keiji KAWACHI

Research Center for Advanced Science and Technology, The University of Tokyo 


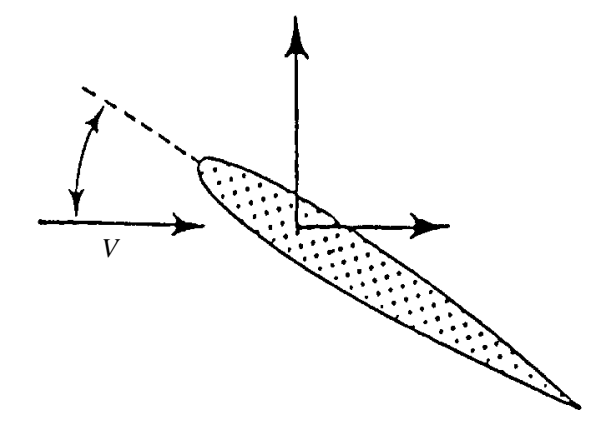

図2 揚力と抗力

している.

一方, 我々のよく知っている航空機の翼やタービン 翼では, 性能のよい翼断面は図2 に示すように前縁が 丸く後縁が尖り, 翼弦長の $10 \sim 15 \%$ 程度の最大厚みを もつた美しい流線型をしていて, 昆虫の翅断面とは似 ても似つかない.このような差は光れ光れのサイズに とって最も適した形状をとることにより生ずることが, ようやく定量的に明らかになってきだ2).

\section{2 流体力と運動器官の大きさ}

自然界や人工物の運動・推進器官を,レイノルズ数 で整理してみると図3のようになる.レイノルズ数は 物体に働く慣性力 (圧力) と粘性力の比で, 物体の大 きさと速度をかけたものを動粘性係数（粘性係数と密 度の比) て割った值として計算される. 水中と空中の 動粘性係数の大きさの違いにより, 水中のレイノルズ 数は小型や低速の運動器官でも思いのほか大きく, 多 くの水中生物が大型の陸鳥の運動器官や航空機の翼に 近い大きなレイノルズ数 $\left(R e \geqq 10^{4}\right)$ て作動する.一般 にサイズの大きな運動器官は, サイズの小さなものよ り高速で動く.このため, 水中と空中の違いを除くと, 運動器官のサイズが大きなものから小さなものへと変 化すると,レイノルズ数も乥れに見合ってほぼ同じよ うに変化していく.

図2に示すように,物体の前進方向（物体に固定した 座標で考えると, 物体に対する一樣流速) に直角方向 の流体力を揚力, 平行な流体力を抗力という. 揚力は慣 性力だけから発生し, 抗力は慣性力と粘性力の両方か ら発生するので, 図3に示すように, レイノルズ数が大 きくなると揚力が卓越し, 小さいと抗力か支配的にな る. 我々のよく知っているレイノルズ数が $10^{5}$ 以上の世 界 (空中ではメートルのサイズ, 乥して水中では10セ ンチメートルのサイズ) では, よくできた翼型の揚力 は抗力の100倍に達する.つまり理論的には, $1 \mathrm{~N}$ で前 へ引つ張ると $100 \mathrm{~N}$ の重さを持ち上げることができる.

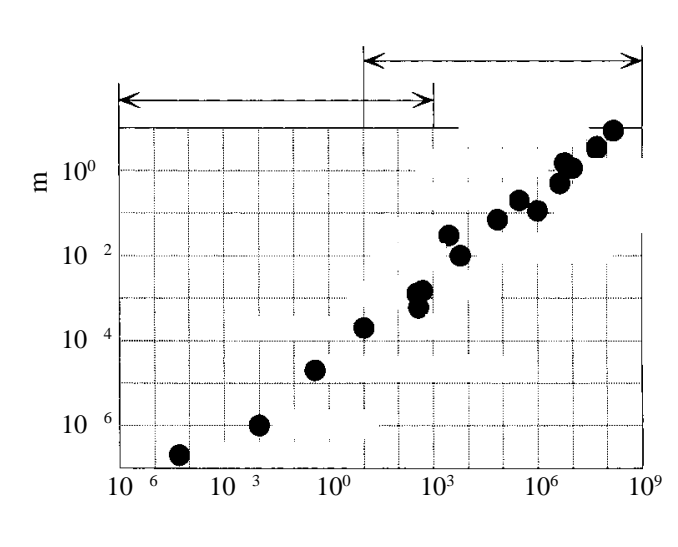

図3運動器官の大きさとレイノルズ数

したがって, この世界では人工物も生物もほとんどす へてて運動器官力湯力を利用している. しかし, 物体の サイズが咸少し,レイノルズ数がさくなると, 揚力と 抗力の比 (揚抗比) は急激に低下していく.レイノル ズ数が1000のオーダー, すなわち, 昆虫の飛行領域で は揚抗比は約10倍になり,さらにレイノルス数が10の 領域になると, 揚力と抗力は同程度になってしまう.し たがって, これ以下のレイノルズ数領域では, 翼を使っ て揚力を発生するよりも, パラシュートのように抗力 を使って飛翔するメカニズムか採用されるようになる. タンポポの綿毛やキノコの胞子が風のまにまに漂って 風下へ流されていき, 風と直角方向の運動ができない のは, このような理由による. したがって, 私たちはレ イノルズ数10の領域が, 翼の最小サイズであると考え ており, 昆虫の飛行領域はちょうどここに相当する.

\section{3 羽ばたき運動}

生物にとっても人工物にとっても翼の揚抗比はとて も大事である. 水平定常飛行をしている航空機では, プ ロペラやジェットエンジンの発生する推進力と抗力と が釣り合い, 重力と揚力が釣り合う.したがって, 揚抗 比の大きな翼ほど, 同じエンジンやプロペラを使って, より重い物体を持ち上げることができる. 一方, 生物の 羽ばたき飛行では, 以下に説明するように翼は推進力 と上向きの力をともに発生する. 翼のある断面を考え, 弚こに働く空気力を考えよう. 図4に示すようにこの 場合は生物の前進速度に加えて, 羽ばたき運動による 翼断面の速度 $r \dot{\beta}$ が生ずる.ただし, $r$ は翼の付け根から 翼断面までの距離, $\beta$ は羽ばたき角である. 产の結果, 打 ち下ろし中の翼に対しては, 斜め下方から上向きに相 対速度 $V$ が生ずる. この相対速度に直角に翼断面の揚 力が発生し, 平行に抗力が発生する. 上向きの相対流速 

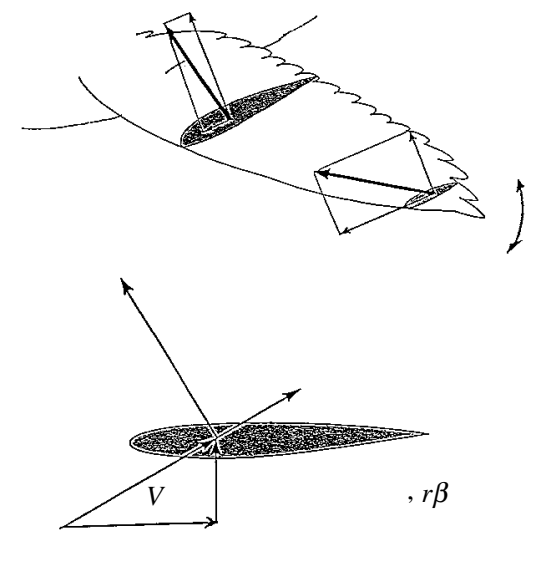

図4はばたき飛行のメカニズム

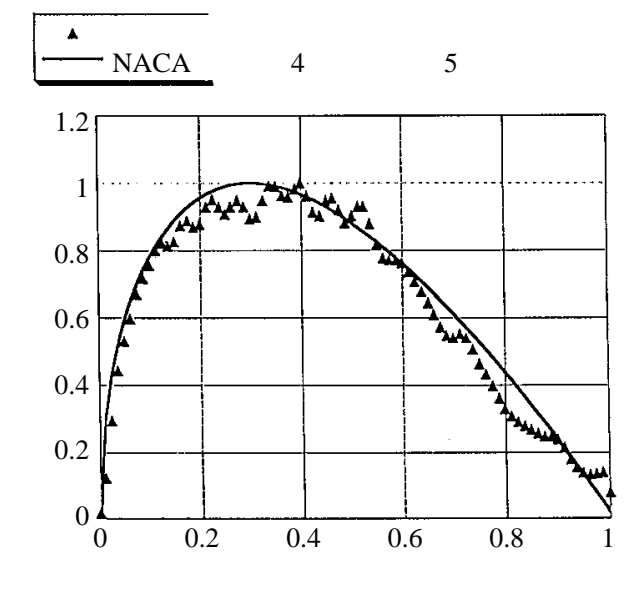

図5 マグロの尾びれと飛行機の翼

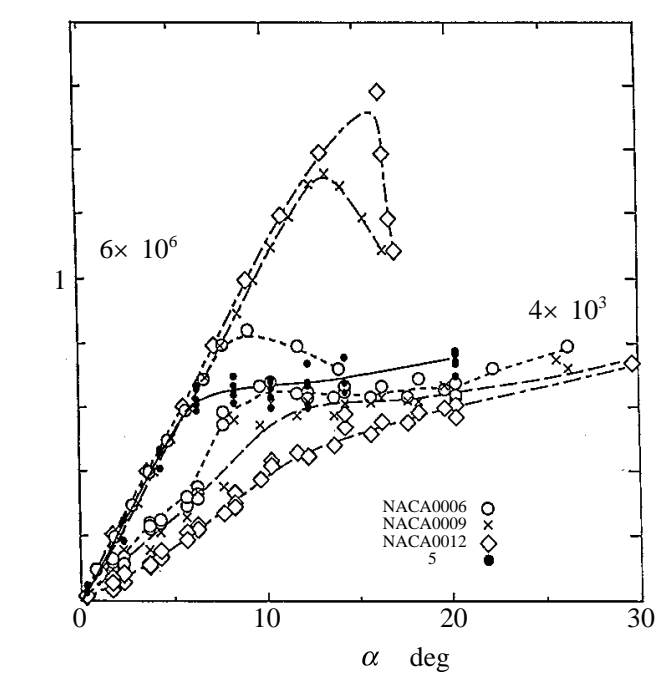

図6 揚力係数と翼の厚み

していることを示している.ただし,この結果は最もよ く一致した箇所のデータを示したものであり, 同じ個 体でも尾びれの他の断面ではもう少し差異が大きい.

さて, この流線型の翼について, 翼の厚みと揚力の関 係を迎角 (翼と相対速度のなす角, 図2参照) に対して 示すと,レイノルス数 $10^{6}$ の領域では図6のようになる 3). 図中の記号 (NACA00**) はNACAで開発された 翼型を示すもので, 最後の 2 文字は最大翼厚と翼弦長の 比をパーセントで表した数字である. 図からわかるよ うに, この範囲内では厚い翼ほど大きな揚力を発生す る. しかし, 翼のサイズがさくなってレイノルス数が $10^{4}$ のオーダーになると, 厚みによる差はほとんどなく 


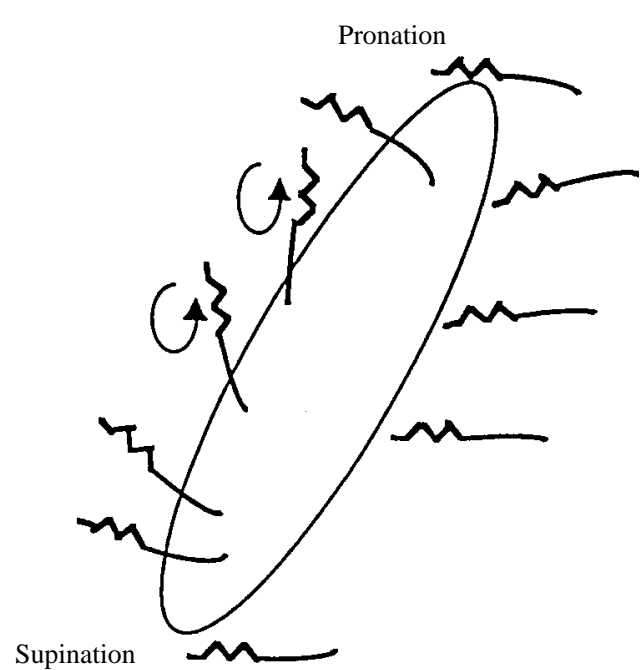

図 7 トンボの翅の断面形状

なり, 昆虫の飛行領域である $10^{3}$ のオーダーになると薄 い翼ほど良好な性能を示すようになる2). また, 同じ平 均厚みをもつ翼では, 流線型よりも単なる平板の方が 大きな揚力を発生できる. ただし, 翼のレイノルズ数が $10^{6}$ から $10^{3}$ へと小さくなるにつれ, 最大揚力は急激に 低下する.

メートルサイズ (レイノルズ数 $10^{5}$ 以上) の翼型につ いては従来より膨大な研究が行われ, 詳細なデータベー スが得られているが, 昆虫の飛行領域ではこれまであま り研究が進んでいなった. 我々は種々の翼型をレイノ ルズ数 $10^{3}$ の領域で実験的に調べ, (1薄けれは薄いほど, 乥して(2)適度の反りのあるものが優れた特性をもって いることを見出した. また, 上下にギザギザのついたも のは, 同じ厚みをもつ平板と比べるとやや揚抗比か悪化 するが, ギザギザがあると翼端方向の曲け岡性とねじり 岡性がともに増加するので(4), 同じ岡性をもつ平板と比 べると,ギザギザの翼のほうがはるかに薄くなり, 光の 結果空力特性も優れてくる. 図7に, 飛行中のトンボの 翅の 1 断面をレーザシートによって可視化し, 兴の形状 の変化を観察した結果を示す5). この図から, 実際の昆 虫も上に記した優れた翼断面の形状をすべて備えてお り,さらに打ち下ろしと打ち上げで翼断面のねじりを 大きく変えるとともに, 反りの向きを反対向きに制御 していることがわかる. このような翼型の制御により， 打ち下ろし時には大きな上向きの力を発生でき, 乥し て打ち上け時には下向きの空気力を極力少なくすると ともに前進方向の大きな空気力を発生できる.

\section{3 . 昆虫の翅の非定常空気力}

昆虫の羽ばたき運動の周波数はきわめて大きい. ンボて約 20〜 $30 \mathrm{~Hz}$, ハチや八エでは100〜 $200 \mathrm{~Hz}$, 蚊 になると300〜 $1000 \mathrm{~Hz}$ に達する.羽ばたき運動では翅 か静止状態から加速し, 最大速度に達した後, 減速し静 止して打ち下ろし過程を終了し, 再び打ち上け過程で 同樣の加減速を繰り返してようやく1サイクルの運動 となる.このため, 翅の迎角も, 空気に対する相対速度 も, 羽ばたき運動の1サイクルで大きく変動する. この ような変動のある翅に働く空気力の大きさを簡単に見 積もるには, 準定常の方法を用いる. これは一定の迎角 と相対速度に対する翼の空気力 (これを定常空気力と 呼ぶ）を実験や理論により求めておき, 羽ばたき運動 のような非定常運動に対しては, 兴の時々刻々の迎角 と相対速度に対応する定常空気力の值を用いて1サイ クルの空気力を推定しようというものである.これま で述べてきた説明は, 理解を容易にするためにこの準 定常の方法に基づいている. しかしW eis Foghは, 1970 年代にコバチのホバリンク飛行を調べ, 準定常の方法 の約2倍もの空気力が働いていることを見出し, 新しい 非定常空気力発生のメカニズムを提案した ${ }^{6)}$. これ(, 従来, 航空機の分野で知られていた非定常運動に対す る空気力 (非定常空気力) の常識7) を覆すものとして 大きな注目を浴びた.

彼の計算は昆虫の重量, 羽ばたき翼の運動面積, 翼の 半径と羽ばたき周波数という当時でも信頼性の高い計 測データだけに基づいた優れたものであり, 兴の後の 研究の出発点となった. 現在でも, ホバリング中の昆虫 の発生する空気力は, 準定常空気力の約2倍ということ が多くの研究から確かめられ続けており,「マルハナ バチは飛べい」という有名なジョークの源になって いる. しかしWeis Foghの提案した非定常空気力発生 のメカニズム自体は, 弚の後の研究により修正が必要 になってきたように思える.WeisFoghのメカニズム は, 図8に示すように, 左右の翅を開いた瞬間に空気が 光の間に流れ込み, 翅の回りに回転する流れ (循環 $\Gamma)$ を形成し, 光の後の羽ばたき運動による速度 $r \beta$ が生じ たとき, 上面の流机下面より速くなり, 上面の圧力が 下面より低下して付加的な空気力が発生するというも のである. しかし, 単独の2次元翼を静止状態から加速 度運動させても, 図 9 に示すように準定常の方法 (破 線) の約 2 倍の流体力が発生すること，またこの結果は 航空機に適用される非定常理論 (一点鎖線) では説明 できないことが明らかになった ${ }^{8)}$.さらに, チョウの翅 のようにずんぐりとした平面形状 (低アスペクト比) の羽ばたき翼の回りの流れは, 図 10 に示すようにWeis Foghメカニズムによるものとはまるで違っており, こ 


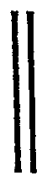

(1)

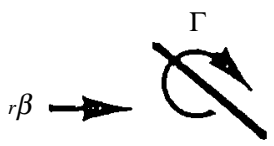

(3)

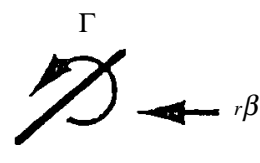

図8 従来の非定常空気力発生モデル

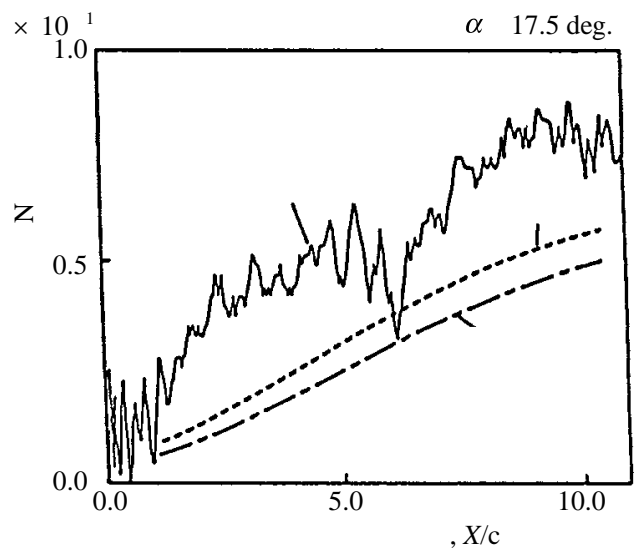

図9加速度運動中の流体力 ${ }^{81}$

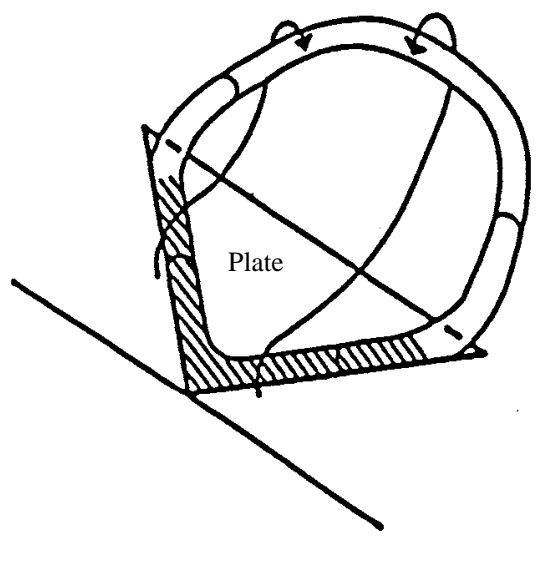

図10 低アスペクト比翼の渦 ${ }^{9}$
の流れを考慮した理論計算結果は, 流体力の計測結果や 実際のチョウの低速飛行とよく一致していることか確 かめられた ${ }^{9,10)}$. また, 2枚の2次元の翼を閉じ合わせて おいてから急激に開いて加速度運動を行うと, 運動の初 期にはW eis Fogh モデルのように付加的な流体力か認 められるが, 产の効果はすぐに消失してしまうことも明 らかになった ${ }^{11)}$. 光して, 単独の翼にサイン波状の並進 運動と回転運動を組み合わせて行わせても, 準定常の方 法の約2倍の流体力が発生する ${ }^{12}$. 一方, ミク口的に見 ると羽ばたき運動中の翼には, 安定な前縁渦が形成さ れ, この部分で強い負圧領域か観察される ${ }^{13)}$. したがっ て, 昆虫が準定常理論值の約2倍の空気力を発生させて 飛行している主原因は, 羽ばたき運動のもつ激しい加 減速運動とねじり運動光して羽ばたき運動中に発生す る渦と翼との干渉であろうと思われる.この付加的な 流体力は単独の翼でも発生するので, ヘリコプタの空 気力の研究で見出された動的失速のモデル ${ }^{14)}$ との整合 性も考慮すると, 2枚の翼の干涉に关の主因を求めた Weis Fogh モデルの修正は避けられないものと思われ る.

4. まとめ

人類の作った航空機の飛行メカニズムと大幅に異な る昆虫の飛行メカニズムは, 光のサイズの小ささや羽 ばたき運動の激しい加減速特性を巧みに利用した優れ たものであることが, 定量的に明らかになってきた. こ れらのメカニズムを工学的に応用することは大変魅力 的であるが, まだ現状では, 簡明な物理モデルで昆虫の 飛行メカニズムの長所を説明することさえ充分にはで きていない.

\section{文 献}

1) Azuma, A. (1992) The Biokinetics of Flying and Swimming, Springer-Verlag, Tokyo .

2) Sunada, S., Sakaguchi, A. and Kawachi, K. (1997) J. Fluids Eng., ASME 119, 129-135 .

3) Abbott, I.H. and Doenhoff, A. (1958) Theory of Wing Sections, Dover, NewYork.

4) Sunada, S., Zeng, L. and Kawachi, K. (1998) J. Theor.Biol. 193, 39-45 .

5 ) Weygandt, J., Kawachi, K. and Ohnuki, T. (1995) Proc. of 48th Annual Meeting of the American Physical Society, EK7.

6) Weis-Fogh, T. (1973) J. Exp.Biol. 59, 169-230.

7) Bisplinghoff, R.L., Ashley, H. and Halfman, R.L. (1955) Aeroelasticity, p.251-272, Addison-Wesley, Mass.

8 ) 砂田 茂 (1992) 東京大学大学院工学系研究科学位 
論文.

9) Sunada, S., Kawachi, K., et al. (1993) J. Exp. Biol. 183, 217-248.

$10)$ Sunada, S., Kawachi, K., et al. (1993) J. Exp. Biol. 183, 249-277.

11) Dickinson, M.H. (1994) J. Exp. Biology 192, 179206.

12 ) 松本有史, 砂田 茂他 (1996) 日本航空宇宙学会第
34 回飛行機シンポジウム講演集, 537-540 .

13) Liu, H., Kawachi, K., et al. (1998) J. Exp. Biol. 201, 461-477.

14) McCroskey, W.J., Carr, L.W. and McAlister, K.W. (1976) AI AA J., 14, 1, 57-63.

\section{【書評】日本分光学会 測定法シリーズ38}

\section{超解像の光学}

河田 聡 編 (学会出版センター) B5 版, 227 ページ, 本体4,600円, 1999年

半導体産業の基盤技術である光リソグラフィーの進 歩に象徵されるように, 光解像技術は「回折限界」に 達し, 弚れをいかに超えるかという努力か続けられて いる. 本書のタイトルにある「超解像 (super-resolution)」とは, 光の回折限界を「超える」ことを意味し ている. このように書くとニアフィールド光学を連想 する人が多いと思うが, 本書は, ニアフィールド光学の 専門書ではない、超解像」を広義にとらえ, 正攻法で あるニアフィールド光学はもちろんのこと,ファーフ イールドで波長の限界を超えるためのさまざまな努力 か紹介されている. 本書は, (1) 超解像の概念と理論, (2) 変形光源と変形瞳による超解像, (3) 共焦点顕微 鏡の超解像, (4) ニアフィールド光学の超解像, (5) 非線形光学による超解像, (6) ディジタル超解像, (7) 超解像光リソグラフィー, (8) 超解像光メモリー, (9) $\mathrm{X}$ 線顕微鏡, (10) 短波長光源, (11) ベクトル回折理 論,の各章から構成されている.「生物物理」の読者が 興味を持つと思われる第 1 章から第6 章の内容を以下 に紹介する. 第1章では, 「超解像」とは何かを要領よ く概説している. 一読しただけでは難しいが, 各論を読 んだ後でもう一度読むとなるほどと思わせる (弚れで も分らなかったら, 各論をもう一回読み直しましょ う). 第2 章では光源・瞳操作力結像特性 (解像度) に 及ぼす効果を説明しており, 例えば「斜め照明」の効 果力理解できる. 第3 章では, 共焦点顕微鏡の原理の説 明と, 最近のレーザーフィードバック顕微鏡, $4 \pi$ 共焦 点顕微鏡力紹介されている. 「共焦点光学系は超解像 なの?」という共焦点顕微鏡ユーザにはお奨めの章で ある. 第4章では, 微小開口によるエバネッセント波の
発生原理と, これを利用したニアフィールド光学顕微 鏡が解説されている. 光して, 走査型トンネル顕微鏡 原子間力顕微鏡との統合など, ニアフィールド光学の 展望が述べられている. ニアフィールド光学の解説書 は少なく, 微小開口のニアフィールド解析を本書のよ うに詳説した書物を他に見たことがない. 本章だけで も手元に置く価値は十分にある. 第 5 章は, 第 2 高調波 や2光子励起顕微鏡などに代表される非線形効果を利 用した顕微鏡技術か紹介されている. 第3〜5章の特徴 として, 最近考案されたさまざまな手法か紹介されて いる. 光の中には, 使え弚うもないものと並んで, 将来, 有効に利用でき乥うな手法もチラリと顔をの艺かせて いる. 顕微光学の研究開発者にとっては, 兴の原石探 しも楽しいかも知れない. 第6章の内容は, ディジタル 処理による信号回復技術とも呼ぶべきものであり, 他 の光学的な超解像技術と相補的に両立できる手法で ある. この技法は, 画像処理を扱うさまざまな分野で 応用可能であり, 画像を扱う研究者にお奨めの章であ る. 本書の全体を通して, フーリエ変換などの数式が 頻繁に登場する. 生物系の研究者には読みにくいと思 われるが, 図が豊富なので, 内容の骨格は理解できる と思う。「超解像」を統一的に論じた書物は少ない. 本書は, 限界を超えようとする顕微光学の研究者にと っては必読の書である. たとえ, 限界を超えようとは 思っていなくても, 実は多くの読者は, 知らないうち に「共焦点顕微鏡」のような超解像技術を使ってい るのである. 本書は, 通常のテキストで顕微鏡の原理 を学んだユーザーが, 違った角度から顕微鏡を学習し 直すのに適した本である. 